Article

\title{
Comparison of Biodiesel Obtained from Virgin Cooking Oil and Waste Cooking Oil Using Supercritical and Catalytic Transesterification
}

\author{
Jeeban Poudel ${ }^{1}$, Sujeeta Karki ${ }^{2}$, Nawaraj Sanjel ${ }^{3}$, Malesh Shah ${ }^{4}$ and Sea Cheon Oh ${ }^{2, *}$ \\ 1 Waste \& Biomass Energy Technology Center, Kongju National University, 1223-24 Cheonan-Daero, \\ Seobuk-gu, Cheonan-si, Chungnam 31080, Korea; jeeban1985@gmail.com \\ 2 Department of Environmental Engineering, Kongju National University, 1223-24 Cheonan-Daero, \\ Seobuk-gu, Cheonan-si, Chungnam 31080, Korea; sujeetakarki@gmail.com \\ 3 Energize Nepal Project, Kathmandu University, 45200 Dhulikhel, Nepal; sanjelnawaraj@gmail.com \\ 4 Department of Mechanical Engineering, Kathmandu University, 45200 Dhulikhel, Nepal; \\ maleshji@gmail.com \\ * Correspondence: ohsec@kongju.ac.kr; Tel.: +82-41-521-9423
}

Academic Editor: S. Kent Hoekman

Received: 3 March 2017; Accepted: 14 April 2017; Published: 17 April 2017

\begin{abstract}
Comparative analysis of transesterification of virgin cooking oil (VCO) and waste cooking oil (WCO) in catalyzed and supercritical transesterification process using methanol and ethanol as solvents has been conducted in this study. The luminous point of this research was the direct comparison of catalytic and supercritical process using the ester composition obtained from virgin cooking oil and waste cooking oil transesterification. Oil to alcohol molar ratio of 1:6 and reaction condition of $65^{\circ} \mathrm{C}$ and 1 bar pressure were considered for the catalytic process, while $260^{\circ} \mathrm{C}$ and high pressure (65 and 75 bar for methanol and ethanol, respectively) were accounted for the supercritical process. Distinct layer separation was observed for both processes. Ester, fatty acid and glycerol composition was studied for both the upper and lower layers separately, from which $100 \%$ ester composition in the upper layer and a mixture of ester and other composition in the lower layer was obtained for the catalytic process owing to succeeding filtration and washing. However, mixture of ester $(>75 \%)$ and other composition was obtained in both layers for the supercritical process where purification process was not implemented. The similarity in the result obtained demonstrates the superiority of waste cooking oil compared to virgin cooking oil, taking cost into consideration.
\end{abstract}

Keywords: biodiesel; supercritical transesterification; catalytic transesterification; virgin cooking oil; waste cooking oil; alcohols

\section{Introduction}

Biodiesel is a soaring alternative to reinstate petroleum-based fuels obtained from renewable sources such as vegetable oil, animal fat and waste cooking oil, due to the fact that the petroleum oil, coal and natural gas are narrowing down and will eventually be exhausted in the near future [1]. Combustion of the non-renewable fossil fuels emits excessive toxic gases like $\mathrm{CO}, \mathrm{CO}_{2}, \mathrm{NO}, \mathrm{NO}_{2}$ and $\mathrm{SO}_{2}$, which are known as greenhouse gases (GHG), and are responsible for the greenhouse effect [2-4]. The use of biodiesel as an alternative fuel is becoming imperative due to the depletion of fossil fuels, and can significantly reduce $\mathrm{CO}$ and particulate matter (PM) emissions as they contain oxygen. Additionally, they have energy security, nontoxicity, local availability and recyclability [5-7]. Furthermore, other advantages for the use of biodiesel are not limited to its lower Sulphur content, improved combustion efficiency, higher biodegradability, domestic origin, and enhanced lubrication properties [6]. Likewise, it can be used in diesel engines in a blended form with conventional diesel 
without modifications of the engine [8-10], although use of only biodiesel poses problems due to its high density, high viscosity, high iodine content, and low volatility [11].

The American Society for Testing and Materials (ASTM) defines biodiesel as mono-alkyl esters of long chain fatty acids (FA) derived from a renewable feedstock, such as vegetable oils, animal fats and used cooking oils [12], via reaction with alcohol such as methanol and ethanol [13]. The acknowledged process used to produce biodiesel is transesterification, which converts feedstock into fatty acid ester with allied properties to that of diesel fuel oil $[14,15]$. Stoichiometrically, transesterification of 1 mole of triglyceride in the presence of 3 moles of alcohol produces 3 moles of fatty acid esters and 1 mole of glycerol, where diglycerides and monoglycerides are the intermediate products. There are four basic approaches for biodiesel production from oils and fats: base-catalyzed transesterification; direct acid-catalyzed transesterification; enzyme catalytic conversion [16-20] of the oil into its FA and then to biodiesel, and non-catalytic transesterification using supercritical alcohols [21,22].

In the catalyzed method, pretreatment is necessary for the oil in which free fatty acid (FFA) exceeds $4 \%$. For the pretreatment, an acid process using sulfuric acid solution can be used in order to reduce the FFA to less than $2 \%$, after which transesterification is effective [23-26]. The purification procedure of the soapy product due to application of catalyst is another complication in the catalyzed method. Meher et al. [27] published an excellent review of biodiesel production by transesterification, which canvasses several successful transesterifications using several low molecular weight alcohols, homogenous acid and base catalysts. Basic homogeneous catalysts have surpassed the acid catalysts because of the faster reaction time. However, for oils with a high concentration of free fatty acids (acid value higher than $2 \mathrm{mg} \mathrm{KOH} / \mathrm{g}$ ), a pre-treatment step is recommended [28]. Heterogeneous catalytic transesterification is also one of the promising technologies for production of biodiesel as the catalyst can be recycled; there is no or very little amount of waste water produced during the process; and, separation of biodiesel from glycerol is much easier [29]. Also, a study by Di Serio et al. suggests the reaction condition to be less drastic compared to the supercritical process [30]. Hernandez et al. [31] introduced a new heterogeneous catalyst by modifying a commercial hydrotalcite for oil transesterification with methanol. Also, the paper advocates about the use of different heterogeneous catalysts by incorporating various references. However, homogeneous and heterogeneous catalytic reactions have several limitations, including sensitivity to high water and FFA content, complicated separation and purification of biodiesel, an enormous amount of reaction time and an exorbitant cost of catalysts which make the process uneconomical. Owing to the limitations of homogeneous and heterogeneous catalytic reactions for biodiesel production, a sustainable and environmentally friendly technology using supercritical alcohols (SCA) has been receiving substantial attention [32]. This supercritical transesterification technology evades many shortcomings posed by the catalytic process. In addition, compared to the catalyzed method, supercritical fluid reaction is expeditious, i.e., long hours of reaction time is considered in the catalyzed method, whereas the supercritical fluid method is completed in a few minutes [33,34]. On the other hand, the supercritical fluid method requires high temperature and pressure, which makes the system economically less viable and also raises issues concerning safety [32]. Moreover, this technology has some limitations related to the harsh operating environment and their effect on the materials. Corrosion and salt deposition are the two main challenges for most of the industrial applications, especially for supercritical water [35]. However, before moving on to the economic analysis, confirming and comparison of the product obtained is indispensable as catalytic transesterification is a well-established commercial process followed all over the world. Therefore, comparison of biodiesel obtained from the catalyzed and supercritical fluid methods was studied. Methanol and ethanol were used as solvents in supercritical fluid method, whereas only methanol was used as reactant for transesterification reaction in the catalytic process. Virgin cooking oil (VCO) and waste cooking oil (WCO) were used as raw materials for biodiesel production. Various research has been accomplished using VCO and WCO so far [36-39]. Demirbas [40] studied biodiesel conversion of waste cooking oil via base-catalytic and supercritical methanol transesterification. However, the comparative study of the catalytic and supercritical 
transesterification process using VCO and WCO has not yet been studied. Furthermore, this study attempts the comparison using two different alcohols_ethanol and methanol.

WCO, which is economical compared to edible vegetable oil, is an insured substitute to VCO. A study on the production cost of biodiesel using animal fat and waste cooking oil as feedstock shows reduction in cost by more than half compared to fresh vegetable oil [41]. Considering the cost factor, waste cooking oil is the raw material for this study although the comparison has been made using the $\mathrm{VCO}$ and WCO.

\section{Experimental Section}

WCO and VCO were used as raw materials in this work. The experiments were conducted using the catalyzed and supercritical fluid methods. Table 1 illustrates the experimental conditions used in this study. The catalyzed transesterification reaction was carried out in a round-bottom flask with heating mantle. The oil was maintained at $60^{\circ} \mathrm{C}$ and a known amount of catalyst $(\mathrm{KOH})$, well stirred with methanol, was introduced in the flask gradually. Generally, in catalyzed transesterification reaction, depending on the percentage of FFA content, less than $2-4 \%$ of the catalyst has proven to be of suitable quantity [34] and, accordingly in our research, we have considered the catalyst amount to be $0.86 \%$ and $1.25 \%$ in VCO and WCO, respectively. The mixture was then allowed to settle down for more than $24 \mathrm{~h}$, which resulted in the formation of two predominant layers in separating funnel. The product mixture of each experiment were primarily stratified, decanted, filtered, washed and finally dried. Water washing of each set was carried out three times with warm distilled water at a temperature of approximately $55{ }^{\circ} \mathrm{C}$, whereas drying was done at $110{ }^{\circ} \mathrm{C}$ and was held at this temperature for $60 \mathrm{~min}$. To shift the equilibrium towards the product side, use of excess alcohol was practiced (oil: alcohol of 1:6 molar ratios) as transesterification reactions are normally reversible.

Table 1. Experimental conditions used in this study.

\begin{tabular}{ccc}
\hline \multirow{2}{*}{ Components } & \multicolumn{2}{c}{ Reaction Method } \\
\cline { 2 - 3 } & Catalyzed Method & Supercritical Fluid Method \\
\hline Molar Ratio (Oil: Alcohol) & $1: 6$ & $1: 6$ \\
Reaction temperature & $65{ }^{\circ} \mathrm{C}$ & $260^{\circ} \mathrm{C}$ \\
Reaction pressure & $1 \mathrm{bar}$ & 65 bar for methanol \\
Reaction holding time & $60 \mathrm{~min}$ & 75 bar for ethanol \\
Catalyst & $\mathrm{KOH}$ & 0 min \\
\hline
\end{tabular}

Figure 1 demonstrates the schematic diagram of the batch-type reactor manufactured by Parr Instrument Co. (USA) with a volume of $25 \mathrm{~mL}$. The permissible reactor conditions are $500{ }^{\circ} \mathrm{C}$ and $55 \mathrm{MPa}$. Methanol and ethanol were used as solvents in the supercritical fluid method. As solvents, methanol (99.5\% purity) manufactured by Ducksan Chemical Co. (Seoul, Korea) and ethanol (99.9\% purity) produced by OCI Company Ltd. (Seoul, Korea) were used. The reaction was carried out at a temperature of $260^{\circ} \mathrm{C}$ for the same molar ratio, i.e., oil and alcohol of 1:6, which ensures the supercritical condition with rigorous stirring at a rate of $500 \mathrm{rpm}$. Instead of varying the individual conditions, the optimum conditions were taken from a previous study [26]. After the preset temperature was reached, the reactor was rapidly cooled in chilled water to stop the reaction immediately. The reaction pressures were 65 and 75 bar while using methanol and ethanol, respectively. The critical temperatures and pressures of alcohols are Tc $=512.6 \mathrm{~K}, 513.9 \mathrm{~K} ; \mathrm{Pc}=80.9 \mathrm{bar}, 61.4 \mathrm{bar}$ for methanol and ethanol, respectively. Therefore, the supercritical fluid reaction in this work was near critical methanol (NCM) and supercritical ethanol (SCE). The products obtained from the catalyzed and supercritical fluid methods were further analyzed by GC-MS (Agilent GC with MSD detector, Agilent technologies, Santa Clara, CA, USA). Table 2 shows the GC analysis conditions for this study. 


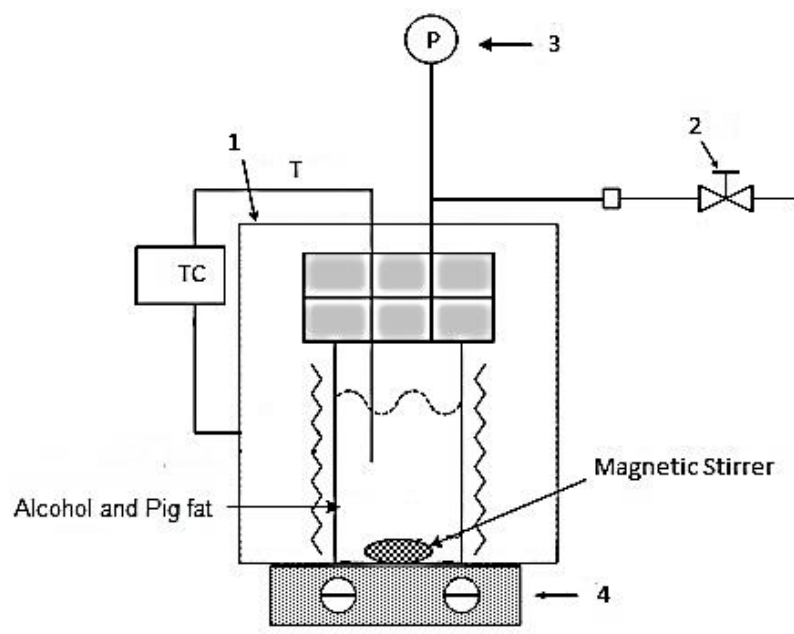

1. Autoclave Reactor

2. Shut-off Valve

4. Hot Plate with Magnetic Stirrer

3. Pressure Gauge

T. Thermocouple

TC. Temperature Controller

Figure 1. Schematic diagram of the experimental apparatus.

Table 2. Operation conditions of GC/MS (Agilent GC with MSD detector) analysis used in this study.

\begin{tabular}{cc}
\hline Instrument & Condition \\
\hline GC & $6890 \mathrm{GC}$, Agilent \\
MSD & 5975 , Agilent \\
\hline Methods & \\
\hline Column & DB-WAX $(30 \mathrm{~mm} \times 250 \mathrm{um}, 0.25 \mathrm{um}$ thickness $)$ \\
Oven temperature & $250^{\circ} \mathrm{C}$ at $5{ }^{\circ} \mathrm{C} / \mathrm{min}$ \\
Carrier gas & $\mathrm{He}, 1 \mathrm{~mL} / \mathrm{min}$ \\
Injection volume & $1 \mu \mathrm{L}$ \\
Detector temperature & $250{ }^{\circ} \mathrm{C}$ \\
Mass scan range & $29-800 \mathrm{amu}$ \\
\hline
\end{tabular}

\section{Results and Discussion}

The FA and FFA composition obtained for VCO and WCO is depicted in Table 3. FFA content of the reactant triglyceride was determined by titration against $0.1 \mathrm{M} \mathrm{KOH}$ solution using phenolphthalein as the indicator. From Table 3, it can be observed that FFA content in WCO increased after cooking. The FA content of 18:2 in WCO is significantly higher than in VCO, whereas the FA content of 18:3 is lower for WCO due to the oxidative cleavage of double bonds during cooking [42]. The term defined by "others" include ester components other than the abovementioned esters. The virgin oil may even include some insoluble solids such as meal and metal oxides from the processing units along with significant amounts of phospholipids in the form of impurities $[43,44]$. The GC analysis of the VCO and WCO is shown in Figure 2. The horizontal component in the GC curve is the retention time, while the vertical component denotes the abundance of the particular component. From the figure, it can be inferred that all the FA composition is detected after retention time of $40 \mathrm{~min}$ for the GC condition. The components obtained after retention time of $40 \mathrm{~min}$ was considered as the raw material composition. 
Table 3. Fatty acid compositions of virgin cooking oil (VCO) and waste cooking oil (WCO) used in this study.

\begin{tabular}{|c|c|c|c|c|c|c|c|}
\hline \multirow{2}{*}{ Sample } & \multicolumn{6}{|c|}{ Fatty Acid (FA) (wt \%) } & \multirow{2}{*}{$\begin{array}{l}\text { Free Fatty Acid } \\
\text { (FFA) (wt \%) }\end{array}$} \\
\hline & $13: 2$ & $16: 1$ & $18: 1$ & $18: 2$ & $18: 3$ & Others & \\
\hline $\mathrm{VCO}$ & 6.49 & 9.86 & 2.41 & 13.58 & 58.48 & 9.19 & 0.28 \\
\hline WCO & 3.38 & 9.89 & 2.41 & 36.70 & 43.21 & 4.42 & 3.15 \\
\hline
\end{tabular}

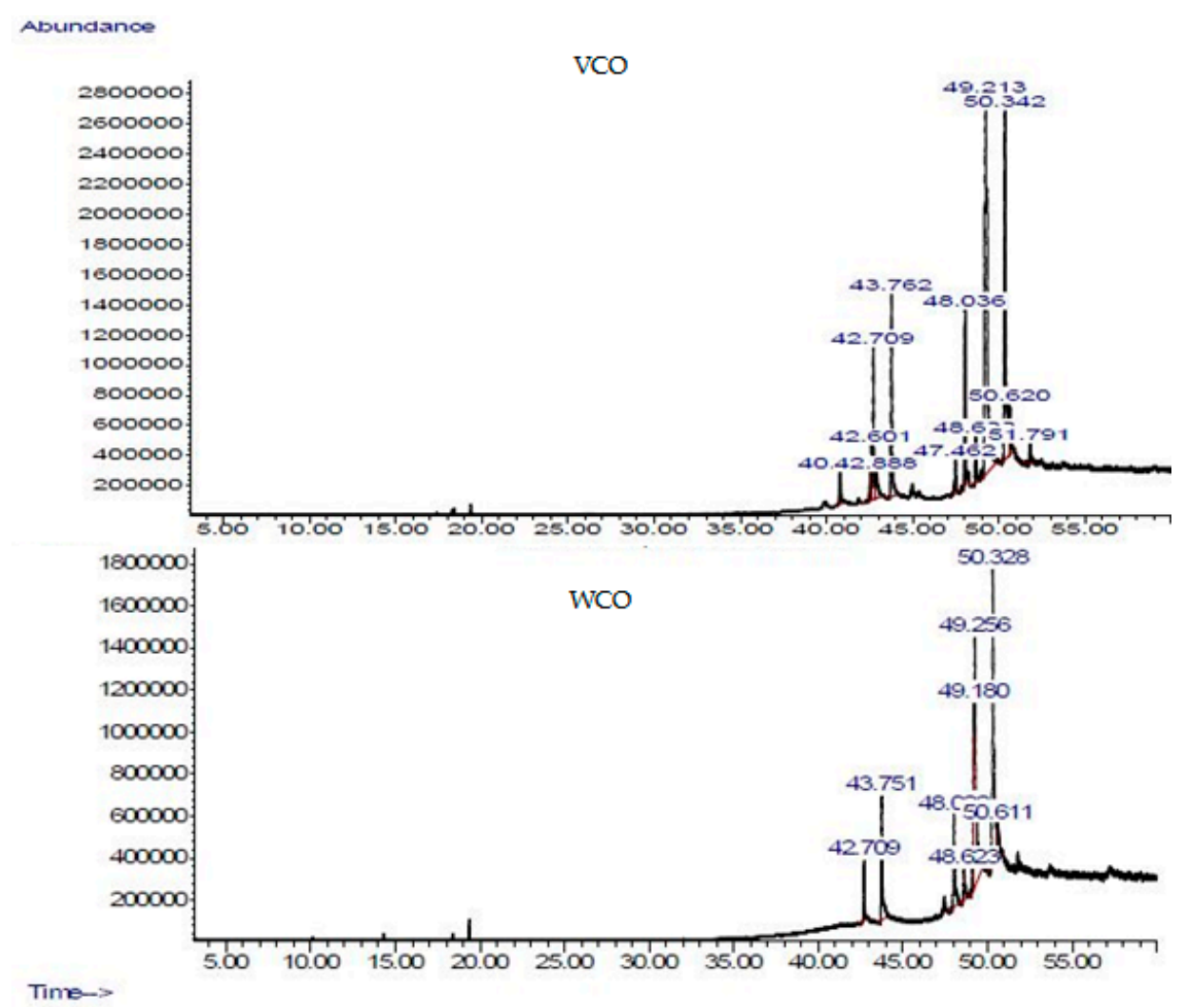

Figure 2. GC chromatogram of VCO and WCO used as raw material.

The pictures of the samples obtained after catalytic and supercritical transesterification are exhibited in Figures 3 and 4, respectively. Clear separation of the ester composition and glycerol layers is visible in all the cases. Figure 5 shows the GC diagram of the lower and upper layers obtained from the catalytic transesterification of VCO and WCO. Figures 6 and 7 illustrate the GC diagram of the lower and upper layers obtained from the supercritical transesterification of VCO and WCO, respectively. The details of GC analysis obtained for catalyzed and supercritical transesterification in terms of fatty acid methyl esters (FAMEs), fatty acid ethyl esters (FAEEs), FA, glycerol and others are arranged in Table 4. Comparing Figures 2 and 5, Figures 6 and 7, all the products obtained before $40 \mathrm{~min}$ were considered as the transesterified products, i.e., FAMEs or FAEEs. The specific composition obtained for all the conditions of Table 4 are included in Tables 5 and 6, where all components are aliphatic compounds. In general, the physical and chemical properties and the performance of methyl esters are comparable to those of the ethyl esters. Methyl and ethyl esters have almost the same heat content. The viscosities of ethyl esters are slightly higher, whereas the cloud and pour points are slightly lower than those of methyl esters [45]. From Table 4 it can be inferred that the upper layer is the biodiesel for catalytic transesterification as $100 \%$ composition is FAMEs attributing to the filtration act succeeding the reactions, whereas the lower layer of WCO and VCO also contains $55.03 \%$ and $44.04 \%$ of esters, respectively. The lower layer comprises the 
mixtures of FAME along with glycerol, FA and other unidentified components. The higher percentage of glycerol in WCO product can be attributed to higher FFA content in the WCO. Contrarily, the supercritical transesterification does not show clear distinction on FAME or FAEE composition although Figure 4 depicts two distinct layers. In NCM condition, VCO and WCO contain significant amounts of FAMEs in both upper and lower layers with considerably higher amounts present in the lower layers, i.e., $96.23 \%$ and $93.67 \%$ for VCO and WCO, respectively. Similarly for SCE, both VCO and WCO have higher FAEEs in the lower layer of the product, i.e., $96.19 \%$ and $94.93 \%$ for VCO and WCO, respectively. For both NCM and SCE, the upper layer contains a significant amount ( $>70 \%$ in all cases) of ester composition. The difference in ester composition is significant for NCM transesterification. This trend in supercritical transesterification is due to the severe experimental conditions where decomposition and regeneration occur simultaneously. Multiple processes of condensation, cyclization and polymerization occur during supercritical reaction [46] in a small reactor, resulting in indistinctive upper and lower layers. Longer residence time and higher volume of the reactor will somehow mitigate these drawbacks. However, longer residence time will have trade-off relations due to multiple processes causing a decrease in FAME or FAEE composition in the product. He et al. [47] evaluated the results obtained for the transesterification of soybean by varying the content of supercritical methanol (SCM) and justified that the decrease in reaction yield is the decrease in the content of unsaturated esters caused by isomerization, hydrogenation and thermal decomposition that consume such esters, especially C18:2 (linoleic) and C18:3 (linolenate), which are more susceptible to thermal decomposition in contrast to mono-unsaturated and saturated esters [48]. So, optimum reaction condition is necessary to countenance the advantage of the supercritical transesterification process over catalytic transesterification. For instance, Kusdiana and Saka [33] obtained a conversion in methyl esters as high as $95 \mathrm{wt} \%$ in about $240 \mathrm{~s}$ in a batch reactor, while Minami and Saka [49] reported conversions of around $90 \mathrm{wt} \%$ in $30 \mathrm{~min}$ reaction for methyl esterification of oleic acid in continuous mode. Conversion of $99.8 \%$ was obtained for SCM and SCE at holding time of 60 min by Jeeban et al. [22] for transesterification of pig fat. Analogous conversion can be obtained at lower holding time by increasing the transesterification temperature or by increasing the voltage of the electrical heater. However, no work yet is able to portray the optimum working condition for supercritical transesterification, as most are still in the elemental phases.

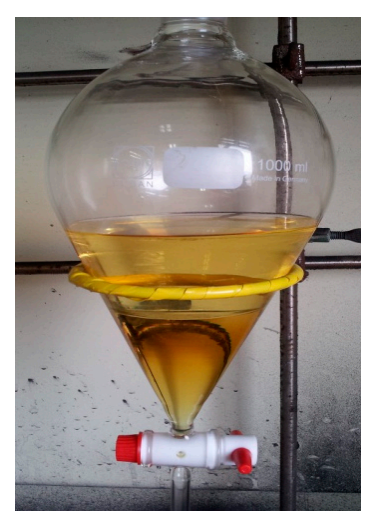

(a)

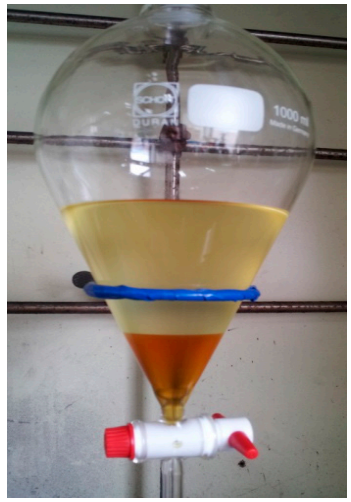

(b)

Figure 3. The upper and lower layer obtained from catalyzed transesterification (a) VCO, and (b) WCO. 


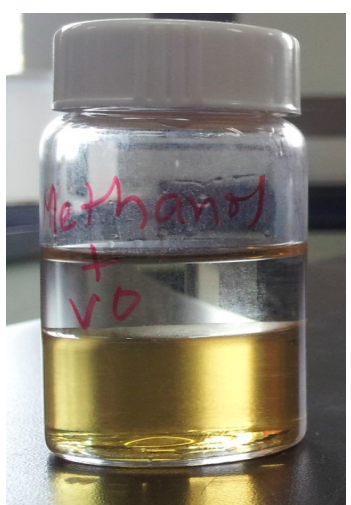

(a)

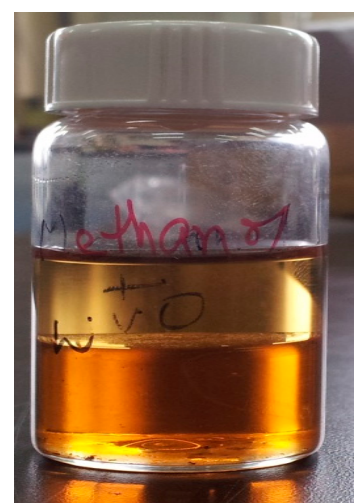

(b)

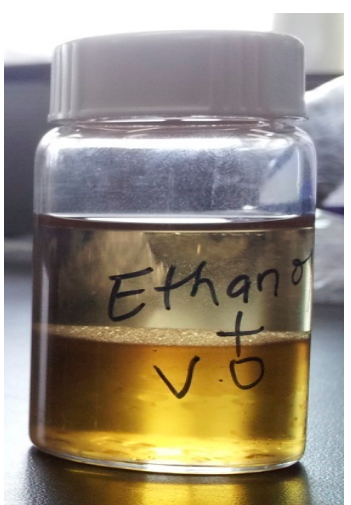

(c)

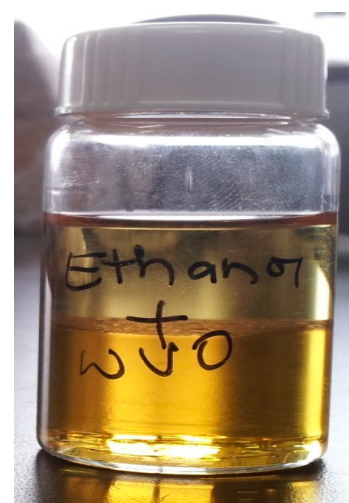

(d)

Figure 4. The upper and lower layer obtained from supercritical transesterification (a) VCO + methanol (b) $\mathrm{WCO}+$ methanol (c) VCO + ethanol, and (d) WCO + ethanol.

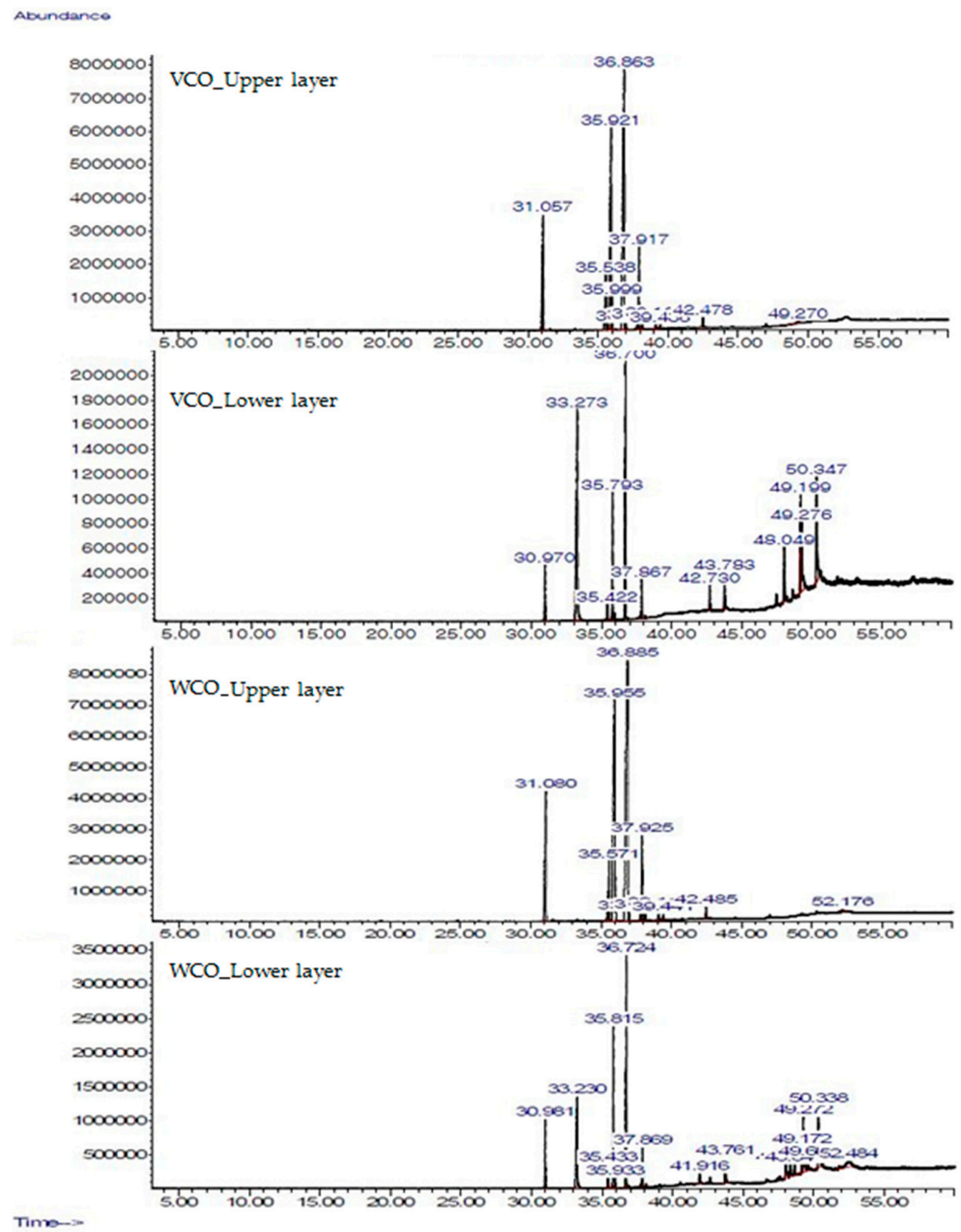

Figure 5. GC chromatogram of products by the catalyzed method. 

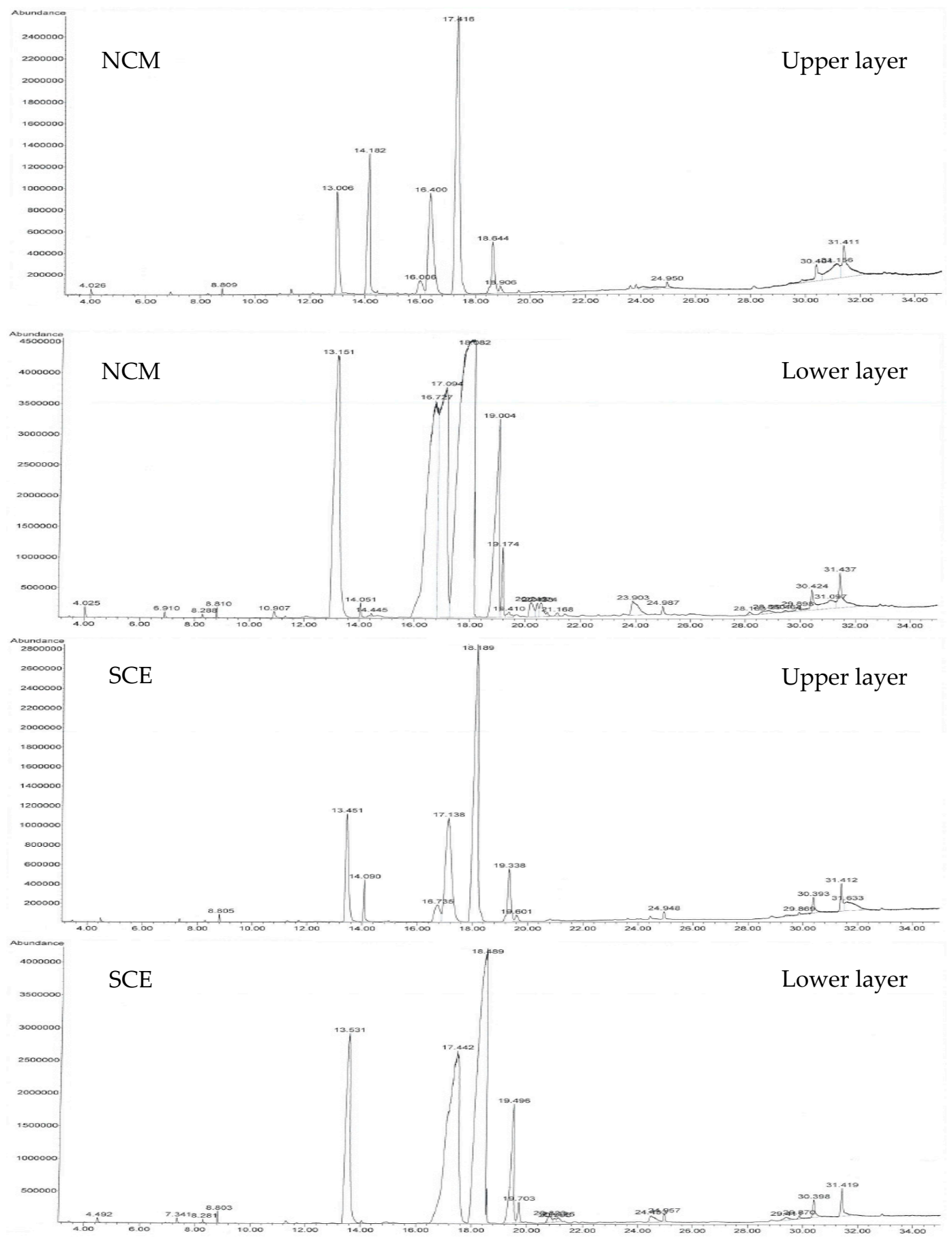

Figure 6. GC chromatogram of products from VCO by the supercritical method. 

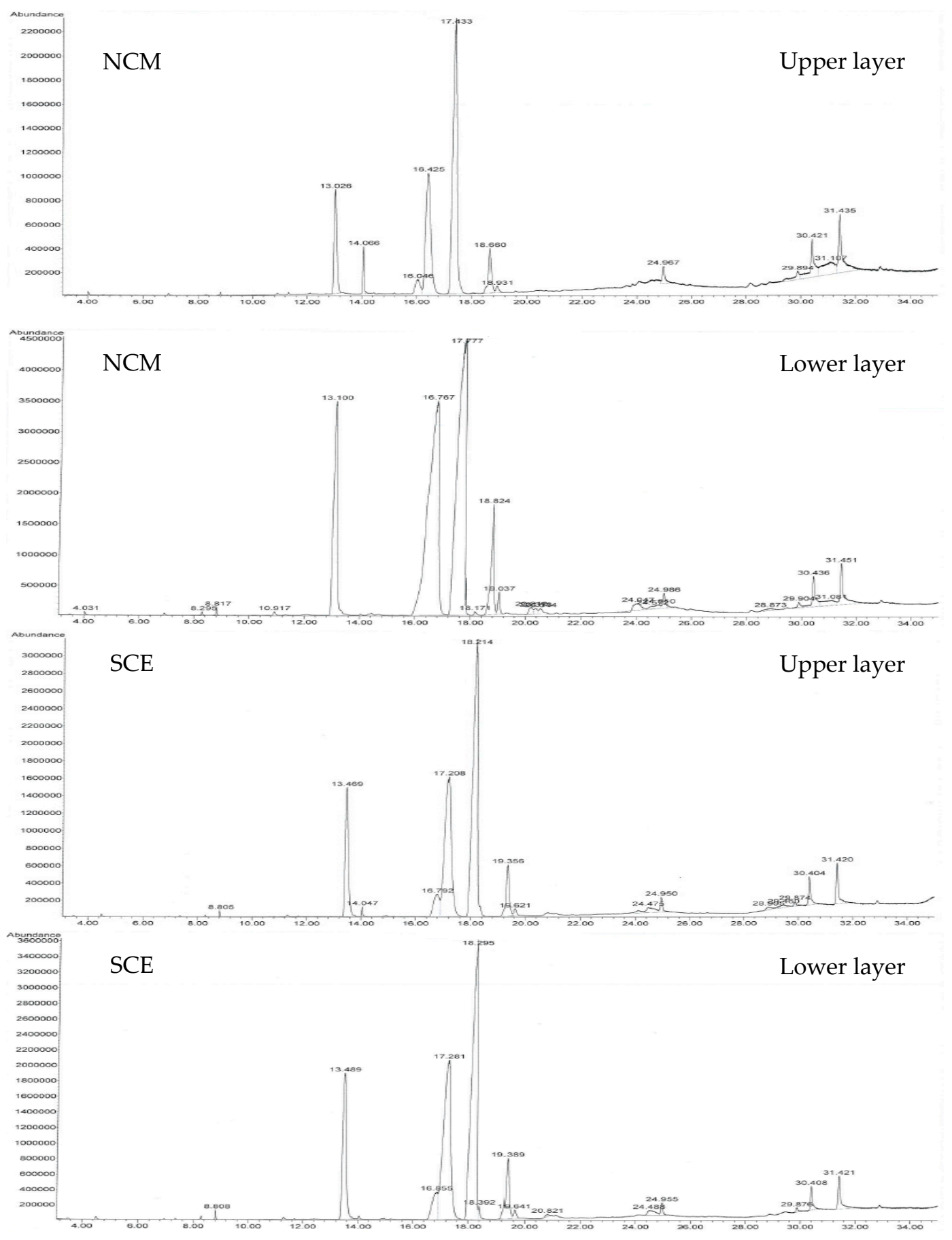

Figure 7. GC chromatogram of products from WCO by the supercritical method. 
Table 4. Compositions of product obtained from catalyzed and supercritical fluid method.

\begin{tabular}{|c|c|c|c|c|c|c|c|}
\hline \multirow{2}{*}{$\begin{array}{c}\text { Raw } \\
\text { Material }\end{array}$} & \multirow{2}{*}{ Method } & \multirow{2}{*}{ Product } & \multicolumn{5}{|c|}{ Composition (wt \%) } \\
\hline & & & FAMEs & FAEEs & FA & Glycerol & Others \\
\hline \multirow{6}{*}{$\mathrm{VCO}$} & \multirow{2}{*}{ Catalyst } & Upper layer & 100 & 0 & 0 & 0 & 0 \\
\hline & & Lower layer & 44.04 & 0 & 21.99 & 28.90 & 8.67 \\
\hline & \multirow{2}{*}{$\mathrm{NCM}$} & Upper layer & 70.50 & 0 & 17.29 & 12.02 & 0.18 \\
\hline & & Lower layer & 96.23 & 0 & 2.35 & 0.16 & 1.26 \\
\hline & \multirow{2}{*}{ SCE } & Upper layer & 0 & 89.40 & 4.10 & 2.11 & 4.39 \\
\hline & & Lower layer & 0 & 96.19 & 2.13 & 0 & 1.68 \\
\hline \multirow{6}{*}{$\mathrm{WCO}$} & \multirow{2}{*}{ Catalyst } & Upper layer & 100 & 0 & 0 & 0 & 0 \\
\hline & & Lower layer & 55.03 & 0 & 24.98 & 14.57 & 5.43 \\
\hline & \multirow{2}{*}{$\mathrm{NCM}$} & Upper layer & 75.91 & 0 & 14.32 & 2.08 & 7.70 \\
\hline & & Lower layer & 93.67 & 0 & 4.54 & 0.28 & 1.51 \\
\hline & \multirow{2}{*}{ SCE } & Upper layer & 0 & 90.27 & 5.95 & 0.38 & 3.40 \\
\hline & & Lower layer & 0 & 94.93 & 4.59 & 0 & 0.49 \\
\hline
\end{tabular}

$\mathrm{NCM}$ = near critical methanol; SCE = supercritical ethanol; FAME = fatty acid methyl esters; FAEE = fatty acid ethyl esters.

Table 5. Components obtained from the catalyzed and supercritical processes of VCO in terms of area $\%$ as obtained from GC analysis.

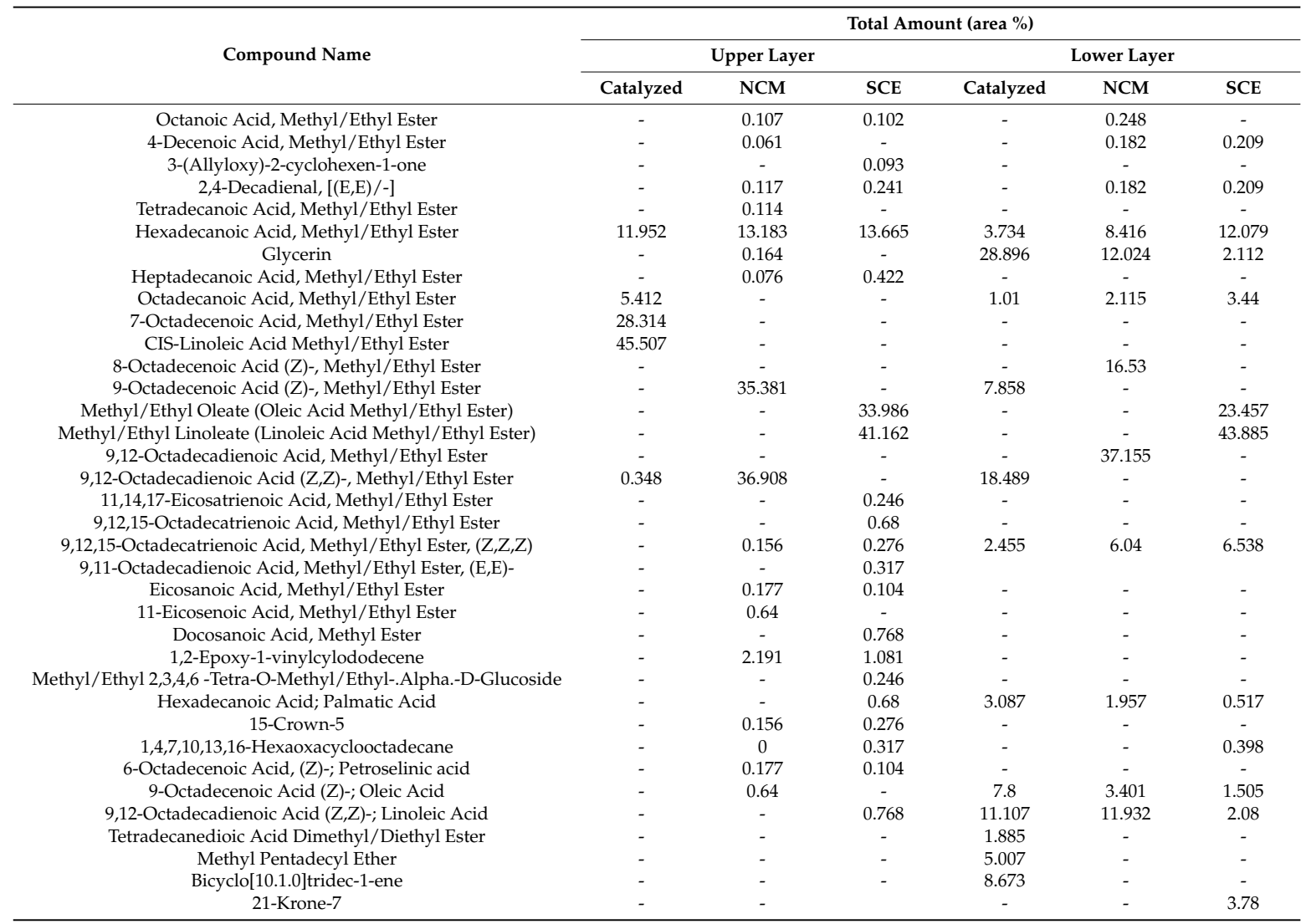


Table 6. Components obtained from the catalyzed and supercritical processes of WCO in terms of area $\%$ as obtained from GC analysis.

\begin{tabular}{|c|c|c|c|c|c|c|}
\hline \multirow{3}{*}{ Compound Name } & \multicolumn{6}{|c|}{ Total Amount (area \%) } \\
\hline & \multicolumn{3}{|c|}{ Upper Layer } & \multicolumn{3}{|c|}{ Lower Layer } \\
\hline & Catalyzed & NCM & SCE & Catalyzed & NCM & SCE \\
\hline 2,4-Decadienal, [(E,E)/-] & - & - & 0.152 & - & - & 0.152 \\
\hline Hexadecanoic Acid, Methyl/Ethyl Ester & 6.301 & 9.315 & 12.846 & 6.301 & 9.315 & 12.846 \\
\hline Glycerin & 13.942 & 2.075 & 0.382 & 13.942 & 2.075 & 0.382 \\
\hline Octadecanoic Acid, Methyl/Ethyl Ester & 1.938 & 2.478 & 3.87 & 1.938 & 2.478 & 3.87 \\
\hline 9-Octadecenoic Acid (Z), Methyl/Ethyl Ester & 14.311 & 21.051 & - & 14.311 & 21.051 & - \\
\hline 10-Octadecenoic Acid, Methyl/Ethyl Ester & 0.786 & - & - & 0.786 & - & - \\
\hline Methyl/Ethyl Oleate (Oleic Acid Methyl/Ethyl Ester) & - & - & 28.822 & - & - & 28.822 \\
\hline Methyl/Ethyl Linoleate (Linoleic Acid Methyl/Ethyl Ester) & - & - & 39.298 & - & - & 39.298 \\
\hline 9,12-Octadecadienoic Acid, Methyl/Ethyl Ester & 26.334 & - & - & 26.334 & - & - \\
\hline 9,12-Octadecadienoic Acid (Z,Z)-, Methyl/Ethyl Ester & - & 37.439 & - & - & 37.439 & - \\
\hline 9,12,15-Octadecatrienoic Acid, Methyl/Ethyl Ester & - & 4.982 & - & - & 4.982 & - \\
\hline 9,12,15-Octadecatrienoic Acid, Methyl/Ethyl Ester, (Z,Z,Z)- & 2.996 & 0.643 & 5.437 & 2.996 & 0.643 & 5.437 \\
\hline Hexadecanoic Acid; Palmatic Acid & 4.366 & 1.586 & 1.056 & 4.366 & 1.586 & 1.056 \\
\hline 1,4,7,10,13,16-Hexaoxacyclooctadecane & 0.778 & 7.7 & 2.902 & 0.778 & 7.7 & 2.902 \\
\hline 2-(bromomethyl) -2-octyl-15-crown-5 & - & - & 0.345 & - & - & 0.345 \\
\hline Octadecanoic Acid & 1.473 & - & - & 1.473 & - & - \\
\hline cis-7,cis-11-Hexadecadien-1-yl Acetate & 2.72 & - & - & 2.72 & - & - \\
\hline 9-Octadecenoic Acid (E)-; trans-Oleic Acid & - & - & 2.001 & - & - & 2.001 \\
\hline 9-Octadecenoic Acid (Z)-; Oleic Acid & 10.103 & 5.343 & - & 10.103 & 5.343 & - \\
\hline Octaethylene Glycol Monododecyl Ether & 1.695 & - & - & 1.695 & - & - \\
\hline 9,12-Octadecadienoic Acid (Z,Z)-; Linoleic Acid & 7.96 & 7.389 & 2.891 & 7.96 & 7.389 & 2.891 \\
\hline
\end{tabular}

Further, there are no traces of FA concentration in the upper layer of the catalyzed method considering the lower layer which contains high amounts of FA that is even higher compared to supercritical transesterification product. The NCM method for both VCO and WCO produces comparatively higher amounts of FA in the upper layer than in the lower layer. However, for the SCE method, both layers contain comparable amounts of FA. The higher amount of FA present in the catalyzed product is the result of lower conversion efficiency of catalyzed transesterification than supercritical transesterification. The absence of FA in the upper layer for the catalyzed process and availability of FA in both layers of the supercritical process is solely due to the filtration and washing succeeding the reactions. The accommodation of proper and efficient purification along with transesterification will elevate the yield of biodiesel using the supercritical method, which is further aided with shorter reaction and processing time [33,34]. Higher amounts of glycerol, i.e., $28.90 \%$ and $14.57 \%$, are obtained from the catalyzed method in the lower layer of the products in VCO and WCO, respectively. Excluding the upper layer obtained while using the NCM method for VCO, which gives $12.02 \%$ of glycerol, other product layers obtained from the supercritical method provides very little amounts of glycerol, ranging from 0 to $2.11 \%$. If closely observed, higher FA and glycerol quantity in Table 4 results in lower composition of esters and vice versa. Higher percentage of FA and glycerol in the NCM compared to the SCE method must be due to the near critical condition of methanol where the solvent did not attain complete supercritical condition, making it partially incapable of taking advantage of superiority of supercritical conditions. It is also evident that at the subcritical state of alcohol, the reaction rate is very low and gradually increases as either temperature or pressure rises [50].

The requirement of high temperature and pressure in supercritical transesterification raises issues concerning safety. However, the absence of a pre-treatment step, soap removal, and catalyst removal can significantly reduce the capital cost of a biodiesel plant while using supercritical transesterification, while the expected high operating cost due to high temperature and pressure can be a major impediment for this technology. Considering the purity of esters and the economic sustainability, continuous production of biodiesel using supercritical transesterification of WCO can compete with the existing alkali- and acid-catalyzed processes. The sensitive key factors for the economic feasibility of the plant are raw material price, plant capacity, glycerol price and capital cost [51]. 


\section{Conclusions}

Two representative transesterification methods used for the production of biodiesel fuel, namely, catalytic and supercritical transesterification were studied in this research. VCO and WCO are emerging concerns in the research for biodiesel production, which are used as raw material in this study. However, the cheap cost factor associated with WCO makes it a propitious substitute to fresh vegetable oil. Since WCO demonstrates similar properties in terms of product, the associated cost and its impact on reducing environmental pollution makes it much more superior than VCO.

The ester composition obtained from the supercritical process is proportionate with catalytic transesterification owing to the fact that the catalytic process has to undergo consecutive filtering and washing, while the product obtained via the supercritical process does not undergo filtering and purification. The shorter reaction time if associated with purification and process optimization, supercritical transesterification will greatly change the course of biodiesel production, which even has a great potential to be established commercially, although economic analysis is imperative.

Acknowledgments: This work was supported by a Grant from Kongju National University, South Korea, and the Human Resources Development Program (No. 20154030200940) of the Korea Institute of Energy Technology Evaluation and Planning (KETEP), funded by the Ministry of Trade, Industry and Energy of the Korean government.

Author Contributions: Jeeban Poudel, Nawaraj Sanjel and Malesh Shah produced the experimental data, prepared figures and tables; Jeeban Poudel, Nawaraj Sanjel, Malesh Shah and Sujeeta Karki wrote the draft of the paper; Sujeeta Karki was responsible for final editing and proofreading; Sea Cheon Oh supervised the research and finalized the paper.

Conflicts of Interest: The authors declare no conflict of interest.

\section{References}

1. Demirbas, A. Biodiesel production from vegetable oils via catalytic and non-catalytic supercritical methanol transesterification methods. Prog. Energy Combust. Sci. 2005, 31, 466-487. [CrossRef]

2. Jayed, M.; Masjuki, H.; Saidur, R.; Kalam, M.; Jahirul, M.I. Environmental aspects and challenges of oilseed produced biodiesel in Southeast Asia. Renew. Sustain. Energy Rev. 2009, 13, 2452-2462. [CrossRef]

3. Murugesan, A.; Umarani, C.; Subramanian, R.; Nedunchezhian, N. Bio-diesel as an alternative fuel for diesel engines-A review. Renew. Sustain. Energy Rev. 2009, 13, 653-662. [CrossRef]

4. Macor, A.; Pavanello, P. Performance and emissions of biodiesel in a boiler for residential heating. Energy 2009, 34, 2025-2032. [CrossRef]

5. Roy, M.M.; Wang, W.; Bujold, J. Biodiesel production and comparison of emissions of a DI diesel engine fueled by biodiesel-diesel and canola oil-diesel blends at high idling operations. Appl. Energy 2013, 106, 198-208. [CrossRef]

6. Roy, M.M.; Calder, J.; Wang, W.; Mangad, A.; Diniz, F.C.M. Emission analysis of a modern Tier 4 DI diesel engine fueled by biodiesel-diesel blends with a cold flow improver (Wintron Synergy) at multiple idling conditions. Appl. Energy 2016, 179, 45-54. [CrossRef]

7. Roy, M.M.; Calder, J.; Wang, W.; Mangad, A.; Diniz, F.C.M. Cold start idle emissions from a modern Tier-4 turbo-charged diesel engine fueled with diesel-biodiesel, diesel-biodiesel-ethanol, and diesel-biodiesel-diethyl ether blends. Appl. Energy 2016, 180, 52-65. [CrossRef]

8. He, B. Advances in emission characteristics of diesel engines using different biodiesel fuels. Renew. Sustain. Energy Rev. 2016, 60, 570-586. [CrossRef]

9. Nalgundwar, A.; Paul, B.; Sharma, S.K. Comparison of performance and emissions characteristics of DI CI engine fueled with dual biodiesel blends of palm and jatropha. Fuel 2016, 173, 172-179. [CrossRef]

10. Lapuerta, M.; Armas, O.; Rodriguez-Fernandez, J. Effect of biodiesel fuels on diesel engine emissions. Prog. Energy Combust. Sci. 2008, 34, 198-223. [CrossRef]

11. Ge, J.C.; Yoon, S.K.; Kim, M.S.; Choi, N.J. Application of Canola Oil Biodiesel/Diesel Blends in a Common Rail Diesel Engine. Appl. Sci. 2016, 7, 34. [CrossRef]

12. Zhang, Y.; Dube, M.; McLean, D.; Kates, M. Biodiesel production from waste cooking oil: 1. Process design and technological assessment. Bioresour. Technol. 2003, 89, 1-16. [PubMed] 
13. Marchetti, J.; Miguel, V.; Errazu, A. Possible methods for biodiesel production. Renew. Sustain. Energy Rev. 2007, 11, 1300-1311. [CrossRef]

14. Primata, M.; Seo, Y.C.; Chu, Y.H. Effect of alkali catalyst on biodiesel production in South Korea from mixtures of fresh soybean oil and waste cooking oil. J. Mater. Cycles Waste Manag. 2013, 15, 223-228. [CrossRef]

15. Kouzu, M.; Kasuno, T.; Tajika, M.; Sugimoto, Y.; Yamanaka, S.; Hidaka, J. Calcium oxide as a solid base catalyst for transesterification of soybean oil and its application to biodiesel production. Fuel 2008, 87, 2798-2806. [CrossRef]

16. Du, W.; Xu, Y.; Liu, D.; Zeng, J. Comparative study on lipase-catalyzed transformation of soybean oil for biodiesel production with different acyl acceptors. J. Mol. Catal. B Enzym. 2004, 30, 125-129. [CrossRef]

17. Oda, M.; Kaieda, M.; Hama, S.; Yamaji, H.; Kondo, A.; Izumoto, E.; Fukuda, H. Facilitatory effect of immobilized lipase-producing Rhizopus oryzae cells on acyl migration in biodiesel-fuel production. Biochem. Eng. J. 2005, 23, 45-51. [CrossRef]

18. Noureddini, H.; Gao, X.; Philkana, R. Immobilized Pseudomonas cepacia lipase for biodiesel fuel production from soybean oil. Bioresour. Technol. 2005, 96, 769-777. [CrossRef] [PubMed]

19. Yucel, Y.; Tekeli, Y. Biodiesel production from canola oil using immobilized lipase. Energy Educ. Sci. Technol. Part A Energy Sci. Res. 2011, 27, 337-346.

20. Demirbas, A. Progress and recent trends in biodiesel fuels. Energy Convers. Manag. 2009, 50, 14-34. [CrossRef]

21. Shah, M.; Poudel, J.; Kwak, H.; Oh, S.C. Kinetic analysis of transesterification of waste pig fat in supercritical alcohols. Process Saf. Environ. Prot. 2015, 98, 239-244. [CrossRef]

22. Poudel, J.; Shah, M.; Karki, S.; Oh, S.C. Qualitative Analysis of Transesterification of Waste Pig Fat in Supercritical Alcohols. Energies 2017, 10, 265. [CrossRef]

23. Ramadhas, A.S.; Jayaraj, S.; Muraleedharan, C. Biodiesel production from high FFA rubber seed oil. Fuel 2005, 84, 335-340. [CrossRef]

24. Alptekin, E.; Canakci, M. Optimization of pretreatment reaction for methyl ester production from chicken fat. Fuel 2010, 89, 4035-4039. [CrossRef]

25. Farag, H.; El-Maghraby, A.; Taha, N.A. Optimization of factors affecting esterification of mixed oil with high percentage of free fatty acid. Fuel Process. Technol. 2011, 92, 507-510. [CrossRef]

26. Sanjel, N.; Gu, J.H.; Oh, S.C. Transesterification Kinetics of Waste Vegetable Oil in Supercritical Alcohols. Energies 2014, 7, 2095-2106. [CrossRef]

27. Meher, L.; Sagar, D.V.; Naik, S. Technical aspects of biodiesel production by transesterification-a review. Renew. Sustain. Energy Rev. 2006, 10, 248-268. [CrossRef]

28. Felizardo, P.; Correia, M.J.N.; Raposo, I.; Mendes, J.F.; Berkemeier, R.; Bordado, J.M. Production of biodiesel from waste frying oils. Waste Manag. 2006, 26, 487-494. [CrossRef] [PubMed]

29. Chouhan, A.S.; Sarma, A. Modern heterogeneous catalysts for biodiesel production: A comprehensive review. Renew. Sustain. Energy Rev. 2011, 15, 4378-4399. [CrossRef]

30. Di Serio, M.; Tesser, R.; Pengmei, L.; Santacesaria, E. Heterogeneous catalysts for biodiesel production. Energy Fuels 2007, 22, 207-217. [CrossRef]

31. Hernandez, M.R.; Reyes-Labarta, J.A.; Valdes, F.J. New Heterogeneous Catalytic Transesterification of Vegetable and Used Frying Oil. Ind. Eng. Chem. Res. 2010, 49, 9068-9076. [CrossRef]

32. Tan, K.T.; Lee, K.T. A review on supercritical fluids (SCF) technology in sustainable biodiesel production: Potential and challenges. Renew. Sustain. Energy Rev. 2011, 15, 2452-2456. [CrossRef]

33. Saka, S.; Kusdiana, D. Biodiesel fuel from rapeseed oil as prepared in supercritical methanol. Fuel 2001, 80, 225-231. [CrossRef]

34. Huaping, Z.; Zongbin, W.; Yuanxiong, C.; Zhang, P.; Shijie, D.; Xiaohua, L.; Zongqiang, M. Preparation of biodiesel catalyzed by solid super base of calcium oxide and its refining process. Chin. J. Catal. 2006, 27, 391-396.

35. Marrone, P.A.; Hodes, M.; Smith, K.A.; Tester, J.W. Salt precipitation and scale control in supercritical water oxidation-part B: Commercial/full-scale applications. J. Supercrit. Fluids 2004, 29, 289-312. [CrossRef]

36. Sirisomboonchai, S.; Abuduwayiti, M.; Guan, G.; Samart, C.; Abliz, S.; Hao, X.; Kusakabe, K.; Abudula, A. Biodiesel production from waste cooking oil using calcined scallop shell as catalyst. Energy Convers. Manag. 2015, 95, 242-247. [CrossRef] 
37. Kouzu, M.; Hidaka, J. Transesterification of vegetable oil into biodiesel catalyzed by CaO: A review. Fuel 2012, 93, 1-12. [CrossRef]

38. Mahesh, S.E.; Ramanathan, A.; Begum, K.M.S.; Narayanan, A. Biodiesel production from waste cooking oil using KBr impregnated $\mathrm{CaO}$ as catalyst. Energy Convers. Manag. 2015, 91, 442-450. [CrossRef]

39. Leung, D.; Guo, Y. Transesterification of neat and used frying oil: Optimization for biodiesel production. Fuel Process. Technol. 2006, 87, 883-890. [CrossRef]

40. Demirbas, A. Biodiesel from waste cooking oil via base-catalytic and supercritical methanol transesterification. Energy Convers. Manag. 2009, 50, 923-927. [CrossRef]

41. Escobar, J.C.; Lora, E.S.; Venturini, O.J.; Yáñez, E.E.; Castillo, E.F.; Almazan, O. Biofuels: Environment, technology and food security. Renew. Sustain. Energy Rev. 2009, 13, 1275-1287. [CrossRef]

42. Köckritz, A.; Martin, A. Oxidation of unsaturated fatty acid derivatives and vegetable oils. Eur. J. Lipid Sci. Technol. 2008, 110, 812-824. [CrossRef]

43. Keith, F.W., Jr.; Blachly, F.E.; Sadler, F.S. Impurities in vegetable oil refining soapstock. J. Am. Oil Chem. Soc. 1954, 31, 298-302. [CrossRef]

44. Ochoa, N.; Pagliero, C.; Marchese, J.; Mattea, M. Ultrafiltration of vegetable oils: Degumming by polymeric membranes. Sep. Purif. Technol. 2001, 22, 417-422. [CrossRef]

45. Encinar, J.; Gonzalez, J.; Rodriguez, J.; Tejedor, A. Biodiesel fuels from vegetable oils: Transesterification of Cynara c ardunculus L. oils with ethanol. Energy Fuel. 2002, 16, 443-450. [CrossRef]

46. Carrier, M.; Loppinet-Serani, A.; Absalon, C.; Marias, F.; Aymonier, C.; Mench, M. Conversion of fern (Pteris vittata L.) biomass from a phytoremediation trial in sub-and supercritical water conditions. Biomass Bioenerg. 2011, 35, 872-883.

47. He, H.; Wang, T.; Zhu, S. Continuous production of biodiesel fuel from vegetable oil using supercritical methanol process. Fuel 2007, 86, 442-447. [CrossRef]

48. Silva, C.D.; Oliveira, J.V. Biodiesel production through non-catalytic supercritical transesterification: Current state and perspectives. Brazil. J. Chem. Eng. 2014, 31, 271-285. [CrossRef]

49. Minami, E.; Saka, S. Kinetics of hydrolysis and methyl esterification for biodiesel production in two-step supercritical methanol process. Fuel 2006, 85, 2479-2483. [CrossRef]

50. Demirbas, A. Comparison of transesterification methods for production of biodiesel from vegetable oils and fats. Energy Convers. Manag. 2008, 49, 125-130. [CrossRef]

51. Van Kasteren, J.; Nisworo, A. A process model to estimate the cost of industrial scale biodiesel production from waste cooking oil by supercritical transesterification. Resour. Conserv. Recycl. 2007, 50, 442-458. [CrossRef]

(C) 2017 by the authors. Licensee MDPI, Basel, Switzerland. This article is an open access article distributed under the terms and conditions of the Creative Commons Attribution (CC BY) license (http:/ / creativecommons.org/licenses/by/4.0/). 